Sournals
INTERNATIONAL JOURNAL OF
ORGANIZATIONAL LEADERSHIP $\begin{gathered}\text { INDUSTRIAL } \\ \text { MANAGEMENT } \\ \text { INSTITUTE }\end{gathered}$

\title{
Antecedents of job turnover in educational sector of Pakistan
}

\author{
Muhammad Rizwan ${ }^{1}$, Asad Afzal Humayon², Ahmad Usman Shahid ${ }^{3 *}$, Rizwan Qaiser \\ Danish $^{4}$, Nauman Aslam ${ }^{5}$, Jawad Shahid ${ }^{6}$ \\ ${ }^{1}$ Institute of Management Sciences, Bahauddin Zakariya University, Multan, Pakistan \\ ${ }^{2,3}$ COMSATS institute of Information Technology, Vehari, Pakistan \\ ${ }^{4}$ Hailey College of Commerce, University of the Punjab, Lahore, Pakistan \\ ${ }^{5}$ Institute of Administrative Sciences, University of the Punjab, Lahore, Pakistan \\ ${ }^{6}$ Institute of Quality and Technology Management, University of the Punjab, Lahore, Pakistan
}

Keywords:

Employee Turnover, Affective Commitment, Job Satisfaction, Job Stress, Organizational Politics, Job Role Ambiguity, Job Formalization.

\section{Received}

09 January 2016

\section{Received in revised form} 23 October 2016

\section{Accepted}

13 November 2016

Correspondence:

ahmadusman1990@ciitvehari.edu. $p k$

\section{Abstract}

The primary purpose of this research was to analyze the effect of affective commitment, job satisfaction, job stress, organizational politics, job role ambiguity, and job formalization on employees' job turnover in private and public sector universities of Lahore, Pakistan. A survey based explanatory research design was used. This study was conducted among the employees working in educational sectors such as universities and colleges in Lahore. About 270 questionnaires were distributed by employing various methods of communication such as email in person and post. The findings of this study indicated that job satisfaction, job stress, organizational politics, and job role ambiguity had significant effects on job turnover of employees while affective commitment and job formalization had adverse effects on the employees. Self-reported measures were used to measure employees' turnover, affective commitment, job satisfaction, job stress, organizational politics, job role ambiguity, and job formalization. Since all the participants were selected from Lahore's public and private universities and colleges, the outcomes were not connected to differences of instructional materials or educational foundations. Considering the importance of employees' turnover, affective commitment, job satisfaction, job stress, organizational politics, job role ambiguity, and job formalization, higher education institutional management and policy makers should take the necessary measures to reduce the extent of turnover which will improve the employees' individual and organizational performance. The relevant literature shows that employees' turnover is under investigation especially in public sector universities of Lahore, Pakistan. So, the current study has contributed to enhance the consideration on the most noteworthy problems. 
Some critical success factors are formed in organizations due to enhancement of worldwide competition and the importance of hiring, holding, and managing resources which improve the effectiveness of organizations. To obtain higher productivity and performance levels, it is essential for organizations to gain their employees' support and contribution. Employee's turnover directly affects on acquiring, training, appraising, and compensating of the human resources. If a large number of employees leave their own organizations over time, their real capabilities are considered controversial which reduce their output levels due to employees' turnover intentions. Employees' turnover not only has a negative impact on the employees' spirits, but also a high turnover rate in an organization may decrease the quality of their performance levels. The factors such as increasing job satisfaction, enhancing employees' affective commitment, reducing the amount of job stress among employees in the workplace, and assigning appropriate organizational policies can have great impacts on increasing or decreasing employees' turnover in both financial and non-financial organizations. The employees' conceptions about organizational policies have a significant impact on employees' moral of those organizations. Previous studies revealed that organizational policies are considered as determinant factors in providing employees' job satisfaction and their plans for leaving the organizations. Beside these challenges, the enforcement of these policies in administrative structure has recently attracted considerable attention. The main theme of this research is to examine the effects of job stress, affective commitment, job satisfaction, organizational policies, and job role ambiguity on employees' turnover intentions.

\section{Literature Review}

\section{Job stress}

In present era, workplace stress increases progressively and changes into one of organizations' feature. A functional method assumes workplace stress as a negative psychological state which is an outcome of building a vibrant collaboration between the employees and their workplaces. Job stress is defined as an employee's non-specific response to the features of the workplace which seems materially threatening (Jamal, 2005). Stress is considered as major causes of organizational ineffectiveness, high employees' turnover and their absence due to illness, lessened excellence, perfection, and extent of attention, amplified expenses of healthcare, and diminished the level of job satisfaction (Wheeler \& Riding, 1994). Rice (1992) proposed job stress as a situation in which task necessities are not in accordance with employees' abilities. Taylor (1999) considered job stress as a passionate response of an excessive task burden. It is also a behavioral response which is provoked by job role ambiguity and work engagement. In previous studies, there is a relationship between job stress and employees' turnover intentions and reasons such as low income self-sufficiency, lower gratitude, and ineffective interaction with colleagues (Blegen, 1993; Hinshaw, Smeltzer, \& Atwood, 1987). The levels of employees' perceived job stress can influence on their job satisfaction which become the main causes of low productivity and employees' turnover intentions in the organizations (Applebaum, Fowler, Fiedler, Osinubi, \& Robson, 2010). Noor and Maad (2008) found a positive relationship between job stress and employees' turnover intentions. Cote and Morgan (2002) argued that stress as a destructive sense is the main cause of reducing job satisfaction and increasing employees' turnover. Actually, stress at work takes a toll on productivity. 


\section{Affective Commitment}

Robbins and Judge (2007) defined affective commitment as the extent to which an employee recognizes particular aspects of a specific organization and its organizational goals and desires to remain as a part of the organization at his current workplace. Affective commitment focuses upon employees' attitude towards their jobs and organizations (Mathieu \& Zajac, 1990). Previous literature suggested that affective commitment is a desire on the part of employee to remain in the organization for its betterment, trust on the organizational objectives, and willingness to support the organization to achieve its objectives (Porter, Steers, Mowday, \& Boulian, 1974). This type of commitment indicates the strength of an employee's participation is determined within an organization and identification with the organization (Porter et al., 1974). Affective commitment has an impact on employee's turnover and employees stay in the organization if they are positively committed to their organizations. The survey instrument which was developed by Meyer and Allen (1991) constitutes both affective and normative commitment to the organization. A major reason to assume affective commitment to predict turnover is the emotional connection to the organization which is characterized by temporary ups and downs depends on variations in organizational procedures, circumstances, and personnel work schedules (Meyer \& Allen, 1997). Because emotions can change swiftly, we may suppose arrogances with great sentimental aspect, restrained at a specific time to relate more strongly to immediate behaviors than those which are temporally distant. An organization's capacity to avoid avert turnover through rising affective commitment levels may be limited. Previous studies concluded that organizational commitment has high negative relationship with employees' turnover (Yin-Fah, Foon, Chee-Leong, \& Osman, 2010). Cho, Johanson, and Guchait (2009) and Fulford (2005) presented a forceful approach that the association between organizational commitment and employees' turnover intentions is negative. Gunlu, Aksarayli, \& Perçin, (2010) proposed that both affective and normative commitment have a substantial impact on turnover intention.

\section{Job Satisfaction}

Job satisfaction refers to employees' feelings and their degree of satisfaction an individual receives for his/her services even if they are negative and positive. Successful organizations intend to preserve higher levels of satisfaction than their opponents because it is thought to influence directly on the productivity and overall efficiency of employees' performance and profitability. According to previous studies, job satisfaction is defined as a set of favorable and unfavorable feelings and attitudes of employees towards their work. Arndt, Arnold, and Landry, (2006) and Arnett, Laverie, \& Meiers, (2003) examined the relationship between variables which are related to job satisfaction and employees' turnover and concluded there was a significant negative relationship between job satisfaction and employees' turnover intentions. Furthermore, they found that factors such as the numbers of years of services and employees' age is directly related to reductions in employees' intentions to quit their jobs. Empirical studies defined job satisfaction as a reliable measure of workers' real sentiments about their job or as a connected matrix of approaches related to different features of the job (Spector, 1997). Poe (2003) argued that the connections which are focusing on the inherent components of job satisfaction are more likely to reduce the employees' turnover. 


\section{Job Turnover}

Turnover is defined as studying the employees' behavioral intentions to quit their jobs or leave their organizations. Tett and Meyer (1993) defined turnover as employees' termination from a specific organization. Actually, it is costly for an organization to replace the new employees instead of leaving ones because the hiring and training a new employee to achieve a benchmark in his/her performance is a time-consuming process (Collins \& Smith, 2006). Turnover intention has been accepted as a prime organizational apprehension in current business organizations (Pfeffer \& Sutton, 2006). There are some reasons for employees' turnover. One of them is due to the unequal collaboration of retiring employees and discharged ones. The second one is because of the difference between intra- and extra-organizational turnovers which are not free and fair. In this regard, intra-organizational turnover refers to movement of employees between departments within the same organization and extra-organizational turnover describes the movement of employees across the organizations. Fishbein and Ajzen (1975) found the factors that forecast the actual reason of turnover are considered as main originators of quitting plan in organizations. Therefore, it is deduced that the intellectual process of employee's intention is the primary reason for actual turnover which is in line with previous studies (Bluedorn, 1982; Mobley, Horner, \& Hollingsworth,1978 ; Steel \& Ovalle, 1984). Intention to quit the organization is proposed as a direct consequence of job dissatisfaction in comparison to actual turnover which is mediated by age and tenure (Hellman, 1997). Karatepe, Uludag, Menevis, Hadzimehmedagic, and Baddar (2006) investigated job satisfaction and employees' turnover intention and finally found out that there was a negative relationship between these two constructs. Job turnover is created when the demand of products and services shift in local as well as international markets (Antelius \& Lundberg, 2003). Job turnover varies from person to person regarding the employees' skills and experiences. When the employees infer that a specific job is not suited according to his skills and abilities then they move to the other sectors or industries (Andersson, Gustafsson, \& Lundberg, 2000). It is also observed that the turnover rate is more for the less experienced employees because they do not feel comfortable in their own organizational environment and they are not used to adapting themselves to the types of organizational practices and procedures. This situation is reversed for qualified and experienced employees and they have low turnover rate (Carson, Carson, \& Bedeian, 1995) because they have already settled themselves in the organizational climate and gained the recognition from the effectiveness of their jobs. Motowidlo and Van Scotter (1994) investigated the contribution of the experienced employees in the fulfillment of the organizational goals and objectives. By keeping employees' morale high as opposed to their competitive organizations, the rate of their turnover reduces and the profitability of the firm increases due to their collaborative working environment. Organizational climate and perceived organizational justice play important roles in employees' turnover intention. Therefore, it is very necessary for the organizations to provide friendly and cooperative working environment and become certain that the organizational justice is met to sustain employees' loyalty. If the organizations fail to maintain the fairness among the employees, it adversely affects the overall performance of the employees and as a consequence increases turnover rate (Andrews \& Kacmar, 2001). Sager and Phillips (1995) observed that workload had significant impact on the turnover rate in different organizations. The firm 
should delegate work to the employees in systematic way that no one feel some bias at managers' part. Sometimes, it is also seen that when the firms put their extra burdens or workloads upon the shoulders of their employees, it adversely affects on their mental perception and therefore they start thinking that they are not well suited for the job and start finding the new job which face them with devastating situation. Work experience as a moderator between the work load and job turnover. In different stages of each career, physiological and psychological conditions of employees are strengthened as time passes. So, they could tackle more effectively the challenging tasks of the firms. Previous studies showed that the overall efficiency of the experienced employees is greater than fresh employees because they know that how they extract the maximum output through optimal utilization of the resources. Organizational commitment has a significant impact on the employees' job turnover. The job commitment or organizational commitment involves psychological feelings which related to intention to quit the job (Rubin \& Brockner, 1975).

\section{Organizational Politics}

Organizational politics is the central characteristics of any organization's culture which takes its routes form the legal and illegal practices of power and authority. It has positive as well as negative consequences on employees' behaviors. Locke (1969) proposed that job satisfaction is a favorable psychological state that is within an institute. Previous literature on organizational politics proposed that the nature of task, freedom to do their work, and coworkers' response can develop with the confidence of workforce in accordance with their job satisfaction and commitment (Anderson, 1994; Kacmar, Bozeman, Carlson \& Anthony, 1999; Witt, Andrew, \& Kacmar, 2000). Organizational politics which described by manipulation and self-interested behavior can possibly deteriorate organizational coordination and efficiency (Kacmar et al., 1999). They consume time without any reason, stop sharing of information, and blocks communication (Eisenhardt \& Bourgeois, 1988). Additionally, they have negative effects on employees. Previous studies suggested that organizational politics sensitivity is linked to intensities of organizational commitment, job performance, and job satisfaction (Ferris, Frink, Bhawuk, Zhou, \& Gilmore, Ferris, Dulebohn, \& Harrell- Cook, 1996; Kacmar et al, 1999). Perceived organizational politics were also found to be related to higher levels of job anxiety and turnover intentions (Kacmar et al., 1999; Maslyn \& Fedor, 1998; Witt, 1998; Witt, Kacmar, Carlson, \& Zivnuska, 2002). Organizational politics is one of the core parts of the organization. It exists in every organization; therefore, it cannot be completely eliminated and we should try to reduce its impact in the organization. It is also one of the main causes of employees' turnover because in the organizational politics every individual in the organization prefers his personal interest over the organizational goals and objectives (Kacmar \& Ferris, 1989) and everyone in the organization try to exploit others in order to attain certain benefits and privileges of his own organization. Organizational politics increase the employees' job turnover because organization positively influence on the levels of employees' job stress (Danish, Humayon, Aslam, Usman, \& Tariq, 2014) and leads to job dissatisfaction which may result in increased job turnover among the employees. 


\section{Role Ambiguity}

Eatough, Chang, Miloslavic, and Johnson, (2011) defined role ambiguity as employees' unclear and vague expectations about their job responsibilities. Role ambiguity comprises uncertain anticipations that are connected with adverse work proficiencies because the misperception of what our role can be considered as a nerve-wracking factor. Fried, Shirom, Gilboa, and Cooper, (2008) and Yun, Takeuchi, \& Liu, (2007) proposed that role ambiguity is significantly related to work stress that affects on employees' job satisfaction because role ambiguity inhibits an employee 's ability to visualize his or her performance and complete his or her own task. Employees are expected to face adverse feelings of nervousness and worry when they are not able to complete their own job descriptions (LePine, Podsakoff, \& LePine, 2005). Ambiguity about a certain type of tasks or job descriptions is considered as a structural characteristic of every organization which substitutes with the situational political behaviors, influence strategies, and organizational politics and insights (Ferris, King, Judge, \& Kacmar, 1991). Job ambiguity increases when job roles, descriptions, and objectives have not been clearly defined and the necessities of reward structure remain vague. Job ambiguity and proper feedback can create such an environment for the actual foundations of political behavior growth. As job ambiguity increases, the employees' certainty about their professional goals and responsibilities reduces (Ashforth \& Lee, 1990). Job role ambiguity is considered as employees' uncertain expectations of their jobs' responsibilities and descriptions. It basically arises when the employees are under a lot of stress due to different work related stressors which they are unable to handle them (Stordeur, D'hoore, \& Vandenberghe, 2001). According to Fried et al (2008) the job role ambiguity is considered as work related stressor which can increase the employees' turnover rate in an organization. Therefore, employees cannot achieve to their own desired goals which causes anxiety and psychological stress and creates the perception that they could not complete their assigned tasks at work (LePine et al., 2005). Jackson, Schwab, and Schuler (1986) explained that job role ambiguity is one of the prime factors influencing to the job stress especially when the employees cannot complete the duties assigned to their positions and are unaware of their own job descriptions and specifications. Confusion and unclearness about the organizational goals and objectives and employees' roles can reduce the employees' performance. All the employees must know all rights and obligations of their organizations so that they can perform their all tasks effectively in a timely manner.

\section{Formalization}

Ford and Slocum (1977) proposed that organizational formalization refers to the degree at which job duties are framed officially by adopting managerial instructions, strategies, and measures. Formalization is the extent to which rules, procedures, and regulations are followed in an organization. Formalized organizational structure comprises of a top down reporting approach and decision-making configuration and it is acknowledged by the presence of obvious categorized principles and rules. A formalized structure constitutes different levels of supervision, chief operations, top level executives or division heads, and central supervisors. It is complimentary to appreciate the necessities of the separate association while forming the structure of an enterprise. The job satisfaction decreases and employees' turnover rate increases 
when the organizational politics exists in the organizations briefly discuss in the theory of reaction. It is mostly exists in organizations where opportunities to gain recognition are limited. This has many negative consequences on the organizations which as a result decrease employees' loyalty, organizational commitment, performance, organizational justice and increase their job turnover. It considers as a hurdle in the progress of any organization which organizations cannot achieve their desired goals and objectives without controlling it. That's why organizations focus on minimizing the impact of organizational politics and strengthening their organizational justice structure in order to build and develop a competitive edge in the market and apply their own market-driving strategies. An overview of this study is presented in the theoretical framework given in Figure 1.

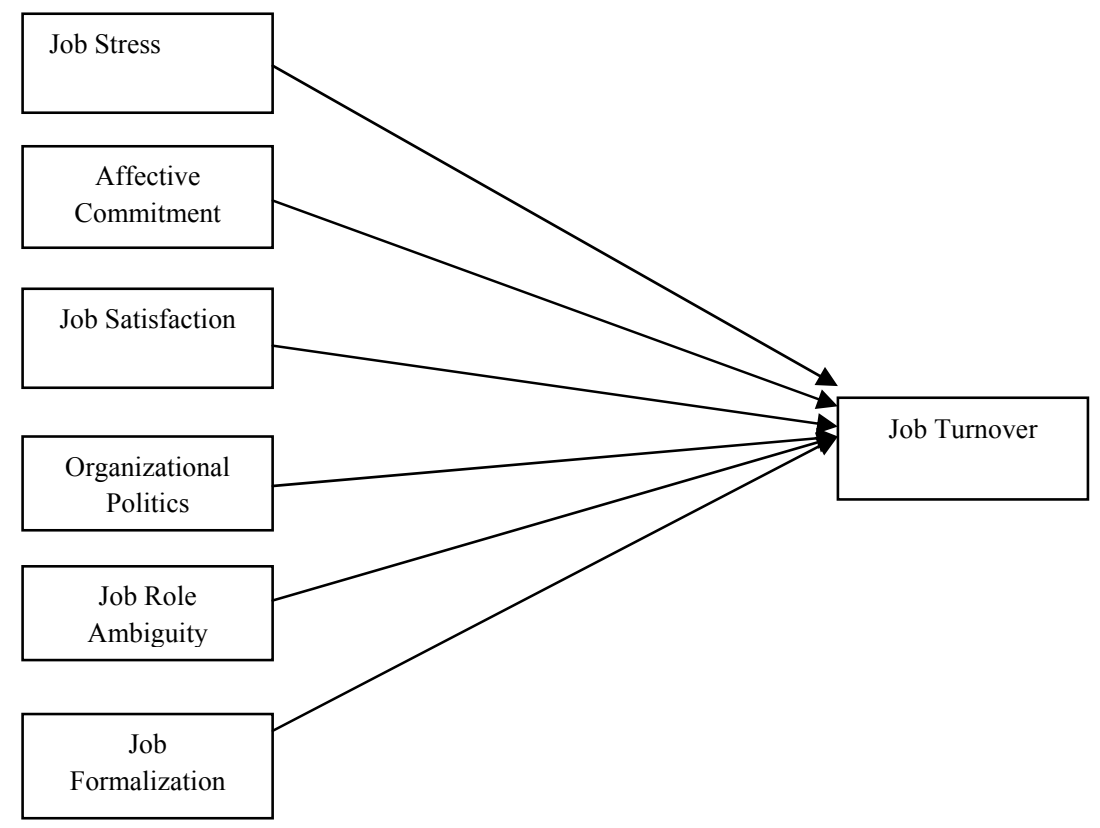

Figure1. Theoretical framework

\section{Research Hypotheses}

In line with the discussion above, the following research hypotheses were formulated:

$\mathbf{H}_{01}$ : There is a significant relationship between employees' job turnover and their job stress.

$\mathbf{H}_{\mathbf{0 2}}$ : There is a significant relationship between employees' job turnover and their affective commitment.

$\mathbf{H}_{\mathbf{0 3}}$ : There is a significant relationship between employees' job turnover and their job satisfaction.

$\mathbf{H}_{04}$ : There is a significant relationship between employees' job turnover and their organizational

politics.

$\mathbf{H}_{05}$ : There is a significant relationship between employees' job turnover and their job role ambiguity.

$\mathbf{H}_{06}$ : There is a significant relationship between employees' job turnover and their job formalization.

\section{Method}


This study revolved around the antecedents of job turnover which were job stress, affective commitment, job satisfaction, organizational politics, job role ambiguity, and job formalization. Data was collected from the employees working in educational sectors of Lahore's colleges and universities through administering 300 adapted questionnaires among the employees of public and private sector universities of Lahore, Pakistan. Only 270 questionnaires were filled out as accurately and completely as possible. The teachers who were working in these universities were selected as statistical population of this study through applying simple random sampling technique. The questionnaire was consisted of two sections including demographic data section and items section related to each construct. Respondents were asked to rate themselves using a five points Likert scale.

\section{Data Analysis}

Table1 summarizes the results of descriptive statistics including mean and standard deviation as well as Pearson's correlation coefficients of both independent and dependent variables. According to Table 1, all variables' mean scores were above the mid-point (2.5) of the scale. The mean scores of job role ambiguity and job turnover allocated the highest and the lowest values to themselves $\left(\mathrm{M}_{\mathrm{JRA}}=3.92 ; \mathrm{M}_{\mathrm{JT}}=2.95\right.$ ). In order to measure the nature and strength of the linear relationships among variables of this study, Pearson's product moment correlation coefficient was run. The results revealed that there were positive temperate relationship between dependent and independent variables. Table 1 shows that the value of job role ambiguity is not significant and therefore it is negatively correlated with the job turnover (0.13). Furthermore, formalization value showed a weak negative correlation with the job turnover $\left(-0.18^{*}\right)$. It also showed that perceived organizational politics was highly significant and moderately correlated with the job turnover $\left(0.34^{* *}\right)$. Both affective commitment and job stress showed high significance level but job satisfaction was negatively correlated $\left(-0.40^{* *}\right)$ whereas job stress correlated positively with the job turnover $\left(0.57^{* *}\right)$ and job stress was negatively associated with the job turnover $(-0.11)$.

Table 1

Descriptive Statistics \& Pearson's Correlation among Variables

\begin{tabular}{|c|c|c|c|c|c|c|c|c|c|}
\hline & Mean & SD & $\begin{array}{c}\text { Job Role } \\
\text { Ambiguity }\end{array}$ & Formulization & $\begin{array}{c}\text { Perceives } \\
\text { Organizational } \\
\text { politics }\end{array}$ & $\begin{array}{c}\text { Affective } \\
\text { Commitment }\end{array}$ & $\begin{array}{c}\text { Job } \\
\text { Satisfaction }\end{array}$ & $\begin{array}{c}\text { Job } \\
\text { stress }\end{array}$ & Turnover \\
\hline Job Role Ambiguity & 3.92 & 0.77 & 1 & & & & & & \\
\hline Formalization & 3.48 & 0.64 & $0.31 * *$ & 1 & & & & & \\
\hline $\begin{array}{l}\text { Perceived } \\
\text { Organizational } \\
\text { Politics }\end{array}$ & 3.00 & 0.48 & 0.04 & 0.09 & 1 & & & & \\
\hline $\begin{array}{l}\text { Affective } \\
\text { Commitment }\end{array}$ & 3.27 & 0.65 & $0.26^{* *}$ & $0.27 * *$ & -0.13 & 1 & & & \\
\hline Job Satisfaction & 3.35 & 0.73 & $0.22 * *$ & $0.21 *$ & 0.14 & -0.07 & 1 & & \\
\hline Job Stress & 3.10 & 0.77 & -0.01 & -0.15 & $0.36^{* *}$ & $-0.25^{* *}$ & -0.01 & 1 & \\
\hline Turnover & 2.95 & 1.00 & -0.13 & $-0.18^{*}$ & $0.34 * *$ & $-0.40^{* *}$ & -0.11 & $\begin{array}{c}0.57^{*} \\
*\end{array}$ & 1 \\
\hline
\end{tabular}


Table 2 shows the results of regression analysis. The results showed that the value of $\mathrm{R}$ was 0.66 which means that 66 per cent of variations exist between job stress, job satisfaction, job role ambiguity, perception of organizational politics, affective commitment, and formulization with the job turnover. The value of R2 was 0.44 which showed that there was overall variation between the independent and dependent variables. Durbin-Watson test was used for measuring the autocorrelation (1.93) which means that there was a positive autocorrelation because it was less than 2. Furthermore, the results showed that the value of $F$ was 17.89. The overall fitness value of the model was significant significance $(0.00)$ which showed that the predictors (job stress, job satisfaction, job role ambiguity, perception of organizational politics, affective commitment, and formulization) had significant impacts on job turnover.

Table 2

Regression Analysis

\begin{tabular}{ccccccc}
\hline Model & $\mathrm{R}$ & $\mathrm{R}^{2}$ & Standard Error & Adjusted $\mathrm{R}^{2}$ & $\mathrm{~F}$ & Significance \\
\hline 1 & $0.66^{\mathrm{a}}$ & 0.44 & 0.76 & 0.41 & 17.89 & $0.00^{\mathrm{a}}$ \\
\hline
\end{tabular}

a. Predictors: Constant Stress, job Satisfaction, Job Role Ambiguity, Formulization, Perceived Organizational Politics, Affective Commitment

b. Dependent Variable: Turnover

Table 3 shows the results of coefficients and multicollinearity. It showed that there was not multicollinearity by examining tolerance and variance inflation (VIF). The highest value of tolerance was related to job satisfaction while the lowest value was associated with job formalization. Similarly, the highest value of VIF belonged to job formalization while the lowest value was associated with job satisfaction.

Table 3

\begin{tabular}{lcccccc} 
Coefficients \& Multicollinearity & \multicolumn{1}{c}{} \\
\hline Model & $\beta$ & $\begin{array}{c}\text { Standard } \\
\text { Error }\end{array}$ & $\mathrm{t}$ & Significance & Tolerance & VIF \\
\hline (Constant) & 2.39 & 0.69 & 3.46 & 0.00 & & \\
Job Role Ambiguity & -0.03 & 0.09 & -0.38 & 0.00 & 0.82 & 1.20 \\
Job Formalization & -0.03 & 0.11 & -0.34 & 0.00 & 0.80 & 1.24 \\
Perceived Organizational Politics & 0.36 & 0.14 & 2.48 & 0.00 & 0.82 & 1.21 \\
Organizational Commitment & -0.41 & 0.11 & -3.76 & 0.00 & 0.81 & 1.23 \\
Job Satisfaction & -0.19 & 0.09 & -2.08 & 0.00 & 0.88 & 1.13 \\
Job Stress & 0.31 & 0.09 & 6.04 & 0.00 & 0.80 & 1.25 \\
Job Turnover & 0.56 & 0.03 & 2.41 & 0.00 & 0.81 & 1.24 \\
\hline
\end{tabular}

\section{Results and Discussion}

This study aimed at examining the effects of job stress, affective commitment, job satisfaction, organizational policies, and job role ambiguity on employees' turnover intentions. The results revealed that there was a significant positive relationship between job role ambiguity and other variables which were job formalization with correlation value of $0.31^{* *}$, perceived organizational politics with correlation value of 0.04 , affective commitment with correlation value of $0.26^{* *}$, job satisfaction with correlation value of $0.22^{* *}$. It also had a negative relationship with job stress with correlation value of -0.01 as well as job turnover with 
correlation value of -0.13 . Results also declared that formalization have positive relationship with perceived organizational politics with correlation value of 0.09 . The correlation value for affective commitment and job satisfaction were $0.27^{* *}$ and $0.21^{*}$, respectively. Formalization had a negative relationship with job stress with correlation value of -0.15 . It also had a significant negative relationship with employees' job turnover with correlation value of -.188*. Results also declared that perceived organizational politics had negative relationship with affective commitment with correlation value of -0.13 and positive relationship with job satisfaction with value of 0.14 . The correlation values for other variables such as job stress and turnover were $0.36^{* *}$ and $0.34^{* *}$, respectively. In the same way, affective commitment had negative relationship with job satisfaction with correlation coefficient of -0.07 , job stress with correlation coefficient value of $-0.25^{* *}$, and job turnover with coefficient value of $-0.40^{* *}$. The correlation coefficient results also showed that there were negative relationships between job satisfaction and job stress as well as job turnover with correlation coefficient values of -0.01 and -0.11 , respectively. Finally, job stress was positively correlated with job turnover with correlation value of $0.57^{* *}$. One of important findings of the study was that organizational politics was moderately correlated with turnover while job stress highly correlated with job turnover. It means that employees who had physically or psychological stress did not perform well and which led to increase in employees' job turnover ratio in the firms. There are two types of politics in the organizations including constructive and destructive in which the former reduced and the later enhanced the existing complexities of the organizations. Employees also perform well when their associations or organizations valued their works, rewarded them, regarded them, and considered them as a fundamental part of their associations. Like some former practical research investigations, this research also had also some limitations. First of all, its sample size was not adequate to be the representative of an entire educational sector. Therefore, the future research in future in an identical industry might predict different results. Second, the data was collected from universities of only one city of Pakistan that's why its results could not be applied to other cities of Pakistan. This exploration provided an organized approach for the recognition of the factors which could affect on employees' job turnover in the educational sectors. This study could help the researchers to investigate other contingent factors which have significant impacts on employees' job turnover and finally propose some alternative strategies in order to reduce their job turnover rate in educational sectors. In this dynamic era, it is very necessary for organizations especially in educational sectors that they efficiently utilize their human resources in their tactical as well as strategic management processes.

\section{References}

Andrews, M. C., \& Kacmar, K. M. (2001). Discriminating among organizational politics, justice, and support. Journal of Organizational Behavior, 22(4), 347-366.

Allen, N. J., \& Meyer, J. P. (1990). The measurement and antecedents of affective, continuance, and normative commitment to the organization. Journal of Applied Psychology, 63(1), 1-18.

Anderson, T. P. (1994). Creating measures of dysfunctional office and organizational politics: The DOOP and short-form DOOP scales psychology. Journal of Human Behavior, 31(2), 24-34.

Andersson, L., Gustafsson, O., \& Lundberg, L. (2000). Structural change, competition, and job turnover in the Swedish manufacturing industry 1964-96. Review of International Economics, 8, 566-582. 
Antelius, J., \& Lundberg, L. (2003). Competition, market structure, and job turnover. Journal of Industry, Competition, \& Trade, 3,211-226.

Arndt, A., Arnold, T. J., \& Landry, T. D. (2006). The effects of polychronic-orientation upon retail employee satisfaction and turnover. Journal of Retailing, 82(4), 319-330.

Arnett, D. B., Laverie, D. A., \& Meiers, A. (2003). Developing parsimonious retailer equity indexes using partial least squares analysis: A method and applications. Journal of Retailing,79(3), 161-170

Applebaum, D., Fowler, S., Fiedler, N., Osinubi, O., \& Robson, M. (2010). The impact of environmental factors on nursing stress, job satisfaction, and turnover intention. The Journal of Nursing Administration, 40(7), 323-328.

Arnett, D. B., D. A., \& Laverie, et al. (2003). Developing parsimonious retailer equity indexes using partial least squares analysis: A method and applications. Journal of Retailing, 79(3), 161-170.

Ashforth, B. E. , \& Lee, R. T. (1990). Defensive behavior in organizations: A preliminary model. Human Relations., 43(7), 621-648.

Blegen, M. A. (1993). Nurses' job satisfaction: A meta-analysis of related variables. Nursing Research, 42(1), 36-41.

Bluedorn, A. C. (1982). The theories of turnover: Causes, effects, and meaning. Research in the Sociology of Organizations, $1(75), 75-128$.

Carson, K. D., Carson, P. P., \& Bedeian, A. G. (1995). Development and construct validation of a career entrenchment measure. Journal of occupational \& Organizational Psychology, 68(4),301-320.

Cho, S., Johanson, M. M., \& Guchait, P. (2009). Employees intent to leave: A comparison of determinants of intent to leave versus intent to stay. International Journal of Hospitality Management, 28(3), 374-381.

Collins, C. J., \& Smith, K. G. (2006). Knowledge exchange and combination: The role of human resource practices in the performance of high-technology firms. Academy of Management Journal, 49(3), 544-560.

Cote, S., \& Morgan, L. M. (2002). A longitudinal analysis of the association between emotion regulation, job satisfaction, and intentions to quit. Journal of Organizational Behavior, 23(8), 947-962.

Danish, R. Q., Humayon, A. A., Aslam, N., Usman, A., \& Tariq, M. I. (2014). Employees perception of organizational politics and job stress at workplace: A comparative study of public and private sector universities. Research Journal of Recent Sciences, 3(7), 1-7.

Eisenhardt, K. M., \& Bourgeois, L. J. (1988). Politics of strategic decision making in high velocity environments: Toward a midrange theory. Academy of Management Journal, 31(4), 737-770.

Eatough, E. M., Chang, C. H., Miloslavic, S. A., \& Johnson, R. E. (2011). Relationships of role stressors with organizational citizenship behavior: A meta-analysis. Journal of Applied Psychology, 96(3), 619-632.

Ferris, G. R., King, T. R., Judge, T. A. , \& Kacmar, K. M. (1991). The management of shared meaning in organizations. In R. A. Giacalone \& P. Rosenfeld (Eds), Applying impression management: How image making affects managerial decisions (pp. 41-64). Newbury Park, CA: Sage Publications.

Ferris, G. R., Frink, D. D., Bhawuk, D. P., Zhou, J., \& Gilmore, D. C. (1996). Reactions of diverse groups to politics in the workplace. Journal of Management, 22(1), 23-44.

Fishbein, M., \& Ajzen, I. (1975). Belief, attitude, intention and behavior: An introduction to theory and research. Reading, MA: Addison-Wesley.

Ford, J. D., \& Slocum, J. W. (1977). Size, technology, environment, and the structure of organizations. Academy of Management Review, 2(4), 561-575.

Fried, Y., Shirom, A., Gilboa, S., \& Cooper, C. L. (2008). The mediating effects of job satisfaction and propensity to leave on role stress-job performance relationships: Combining meta-analysis and structural equation modeling. International Journal of Stress Management, 15(4), 305-328.

Fulford, M. D. (2005). That's not fair! The test of a model of organizational justice, job satisfaction, and organizational commitment among hotel employees. Journal of Human Resources in Hospitality \& Tourism, 4(1), 73-84.

Gilmore, D. C., Ferris, G. R., Dulebohn, J. H., \& Harrell-Cook, G. (1996). Organizational politics and employee attendance. Group \& Organization Management, 21(4), 481-494.

Gunlu, E., Aksarayli, M., \& Perçin, N. S. (2010). Job satisfaction and organizational commitment of hotel managers in Turkey. International Journal of Contemporary Hospitality Management, 22(5), 693-717.

Hellman, C. M. (1997). Job satisfaction and intent to leave. The Journal of Social Psychology, 137(6), 677-689.

Hinshaw, A. S., Smeltzer, C. H., \& Atwood, J. R. (1987). Innovative retention strategies for nursing staff. Journal of Nursing Administration, 17(6), 8-16. 
Jackson, S. E., Schwab, R. L., \& Schuler, R. S. (1986). Toward an understanding of the burnout phenomenon. Journal of Applied Psychology, 71(4), 630-640.

Jamal, M. (2005). Burnout among Canadian and Chinese employees: A cross cultural study. European Management Review, 2(3), 224-230.

Kacmar, K. M., Bozeman, D. P., Carlson, D. S., \& Anthony, W. P. (1999). An examination of the perceptions of organizational politics model: Replication and extension. Human Relations, 52, 383-416.

Kacmar, K. M., \& Ferris, G. R. (1989). Theoretical and methodological considerations in the age-job satisfaction relationship. Journal of Applied Psychology, 74(2), 201-207.

Karatepe, O. M., Uludag, O., Menevis, I., Hadzimehmedagic, L., \& Baddar, L. (2006). The effects of selected individual characteristics on frontline employee performance and job satisfaction. Tourism Management, 27(4), 547-560.

LePine, J. A., Podsakoff, N. P., \& LePine, M. A. (2005). A meta-analytic test of the challenge stressor-hindrance stressor framework: An explanation for inconsistent relationships among stressors and performance. Academy of Management Journal, 48(5), 764-775.

Locke, E. A. (1969). What is job satisfaction? Organizational behavior and human performance. In E. E. Lawler (Eds.), Motivation in work organizations. Monterrey, CA: Brooks/Cole Publishing Company.

Maslyn, J. M., \& Fedor, D. B. (1998). Perceptions of politics: Does measuring different foci matter? Journal of Applied Psychology, 84, 645-653.

Mathieu, J. E., \& Zajac, D. M. (1990). A review and meta-analysis of the antecedents, correlates, and consequences of organizational commitment . Psychological Bulletin, 108(2), 171-194.

Meyer, J. P., \& Allen, N. J. (1991). A three-component conceptualization of organizational commitment. Human Resource Management Review, 1(1), 61-89.

Meyer, J. P., \& Allen, N. J. (1997). Commitment in the workplace: Theory, research, and application. Thousand Oaks, Calif: Sage Publications.

Mobley, W. H., Horner, S. O., \& Hollingsworth, A. T. (1978). An evaluation of precursors of hospital employee turnover. Journal of Applied Psychology, 63(4), 408-414.

Motowidlo, S. J., \& Van Scotter, J. R. (1994). Evidence that task performance should be distinguished from contextual performance. Journal of Applied Psychology, 79, 475-480.

Noor, S., \& Maad, N. (2008). Examining the relationship between work life conflict, stress, and turnover intentions among marketing executives in Pakistan. International Journal of Business \& Management, 3(11), 93-102.

Pfeffer, J., \& Sutton, R. I. (2006). Hard facts, dangerous half-truths, and absolute nonsense:Profiting from evidence-based management. Boston, MA: Harvard Business School Press.

Poe, A. C. (2003). Keeping hotel workers: It takes more than money to retain lower-paid employees. HR Magazine, 48(2), 9192.

Porter, L. W., Steers, R. M., Mowday, R. T., \& Boulian, P. V. (1974). Organizationalcommitment, job satisfaction, and turnover among psychiatric technicians. Journal of Applied Psychology, 59(5), 603-609.

Rice, P. L. (1992). Stress and health. Pacific Grove, CA: Crooks/Cole Press.

Robbins, S. P. , \& Judge, T. (2007). Organizational behaviour. Upper Saddle River, NJ: Pearson Prentice Hall.

Rubin, J. Z., \& Brockner, J. (1975). Factors affecting entrapment in waiting situations: The Rosencrantz and Guildenstern effect. Journal of Personality \& Social Psychology, 31(6), 1054-1063.

Sager, J. K., \& Phillip, H. W. (1995). Clarification of the meaning of job stress in the context of sales force research. Journal of Personal Selling \& Sales Management, 15, 51-64.

Spector, P. E. (1997). Job satisfaction: Application, assessment, cause, and consequences. Thousand Oaks, CA: Sage Publication.

Steel, R. P., \& Ovalle, N. K. (1984). A review and meta-analysis of research on the relationship between behavioral intentions and employee turnover. Journal of Applied Psychology, 69(4), 673-686.

Stordeur, S., D'hoore, W., \& Vandenberghe, C. (2001) Leadership, organizational stress, and emotional exhaustion among nursing hospital staff. Journal of Advanced Nursing, 35(4), 533-542.

Taylor, S. E. (1999). Health psychology. Boston: McGraw-Hill Press.

Tett, R. P., \& Meyer, J. P. (1993). Job satisfaction, organizational commitment, turnover intention, and turnover: Path analyses based on meta-analytic findings. Personnel Psychology, 46(2), 259-293. 
Wheeler, H., \& Riding, R. (1994). Occupational stress in general nurses and midwives. British Journal of Nursing, 3(10), 527534.

Witt, L. A. (1998). Enhancing organizational goal congruence: A solution to organizational politics. Journal of Applied Psychology, 83(4), 666-674.

Witt, L. A., Andrews, M. C., \& Kacmar, K. M. (2000). The role of participation in decision-making in the organizational politics-job satisfaction relationship. Human Relations, 53(3), 341-358.

Witt, L. A., Kacmar, K. M., Carlson, D. S., \& Zivnuska, S. (2002). Interactive effects of personality and organizational politics on contextual performance. Journal of Organizational Behavior, 23(8), 911-926.

Yin-Fah, B. C., Foon, Y. S., Chee-Leong, L., \& Osman, S. (2010). An exploratory study on turnover intention among private sector employees. International Journal of Business \& Management, 5(8), 57-64.

Yun, S., Takeuchi, R., \& Liu, W. (2007). Employee self-enhancement motives and job performance behaviors: Investigating the moderating effects of employee role ambiguity and managerial perceptions of employee commitment. Journal of Applied Psychology, 92(3), 745-756. 